\title{
K prameňom verejnosti: pokus o sociologickú interpretáciu
}

\author{
Ján Stena ${ }^{1}$ \\ Slovenská sociologická spoločnost' pri SAV
}

To the Sources of the Public: An Attempt at Sociological Interpretation. This paper is an attempt to recompose a theory of the public from the position of sociology. The author seeks inspirational stimuli for such a goal in classic conceptualisations (Dewey, Arendt, Habermas, Fraser). He monitors the development of the concept of "publicness" and the penetration of information technologies into this domain. The author attempts to outline in form hypothesis the mechanism by which an individual becomes part of the public. In conclusion, the author discovers the public as a sociabilite ferment, which is the universal ground for social movements and organized associations of civil society. The author's reasoning is based on the metatheory of the morphogenetic approach.

Sociológia 2020, Vol. 52 (No. 2: 153-179)

https://doi.org/10.31577/sociologia.2020.52.2.7

Key words: The public; publicness; social communication; visibility; publicy; privacity; a sociabilite ferment; digital transformation; morphogenetic approach

Realita není, čím se zdá

Carlo Rovelli, autor rovnomenného bestselleru o teoretickej fyzike.

Zdvihnutá vlna masových zhromaždení obyvatel'stva skoro po celom svete $\mathrm{v}$ priebehu prvých decénií 21 . storočia vyvstala pred riadiacimi elitami ako seriózny problém a pred spoločenskými vedcami ako nová výzva. Stala sa o to naliehavejšou, ked’že sociálne pohyby obyvatel'stva podriadeného držitel'om moci korešpondujú s hromadným využívaním informačných technológií, ktoré prelomovo zasahujú do sociálnej komunikácie a sociability. Ukázalo sa, že zvetranou logikou teórie verejnej sféry už nové skutočnosti nemožno spol'ahlivo vysvetlit', preto sa objavil rad návrhov nanovo konceptualizovat' problematiku verejného života, a nie len na pôde sociológie, filozofie politiky, ale i v rámci teórií demokracie, kultúrnych a mediálnych štúdií (pravda s rôznymi epistemologickými orientáciami).

Reflektujem ich prínos bez toho, aby som sa zaoberal ich hodnotením, to, čo ma v nich inšpiruje, rozvíjam v odlišných súvislostiach. Pridávam k nim svoj návrh na rekompozíciu problematiky 'verejného'. Budem sa pritom opierat' o morfogenetický prístup rozpracovaný pre potreby sociológie M. S. Archero$\operatorname{vou}^{2} \mathrm{~s}$ úmyslom overit' či prinesie produktívnejšie konceptuálne riešenia ako doteraz známe pokusy. Budem uvažovat' iba o prostredí demokratických krajín.

Ciel'om štúdie je ponúknut' na diskusiu nové prvky a nazeranie na povahu verejnosti, ktoré neboli prítomné $\mathrm{v}$ tradičných prístupoch a nie sú obsiahnuté ani v súčasných snahách o teoretickú inováciu. Pri riešení otázky, ako

\footnotetext{
1 Korešpondencia: Doc. PhDr. Ján Stena, CSc.; Bratislava, Slovenská republika. E-mail: senior@stena.sk

2 O jeho význame pre sociológiu som referoval v tomto časopise (Stena 2015: 414-437).
} 
dochádza $\mathrm{k}$ pretváraniu množiny osôb na zomknutú verejnost' $\mathrm{v}$ tvare aktéra schopného ovplyvňovat' dianie $\mathrm{v}$ spoločenstve, ponúkam vlastný návrh sociálnych mechanizmov a novší pohl'ad na vzt’ah verejnosti a občianskej spoločnosti.

Bližšie o tom v tretej časti štúdie, ktorej predchádza minimalistické uvedenie do problematiky teórie verejnosti určené čitatel'om, ktorí sa témou doposial' nezaoberali. V úvodnej časti textu upriamujem pozornost' na tie momenty ustáleného pojmového aparátu, ktoré brzdia rozvoj poznania a na myšlienky vplyvných autorov minulosti, ktoré sú nad'alej inšpirujúce. V druhej časti textu, poňatej ako prehl'ad rozpracovanosti témy, uvádzam, ako sa menila realita „verejného" a nadväzne aj súbor adekvátnych pojmov pod vplyvom digitálnej transformácie. $\mathrm{V}$ priebehu výkladu postupne predstavujem najprv tri pohl'ady na verejnost': ako atribútové, príslovkové a napokon substantívne pojmové určenie. Tým chcem naznačit' cestu, akou by bolo možné postupne vyviaznut' z košatých pojmových a terminologických zauzlení.

\section{Konceptuálne dedičstvo}

V tradícii teoretického rozpracúvania sa zvyklo verejnost' (the public) definovat' ako množinu l'udí. Prirodzene fenomén verejnosti bez zal'udnenia nie je možný, ale určujúcim definičným znakom nie je ich prostá prítomnost', ale skôr spoločné konanie a vzt’ahy, aké pritom sami vytvárajú. Vyplýva to tak z koncepcie Hannah Arendtovej, ako aj iných autorov. V diele The Human Condition (1958) poukázala na to, že „verejné، ${ }^{\text {‘3 }}$ sa v starogréckych časoch konštituovalo tak $\mathrm{v}$ rozhovoroch (sporoch) slobodných občanov, ktoré mali podobu porady alebo súdu, ako aj v spoločnom konaní, či už pri vedení vojny alebo pri bojových hrách. Kritici jej oprávnene vytýkajú striktné separovanie dvoch navzájom sa podmieňujúcich domén - oikos t. j. oblast' súkromia určeného ako apolitický komplex fyzických činností nevyhnutných pre udržanie života - a polis, kde sa v pluralite jednotlivcov odohráva verejné dianie, $\mathrm{v}$ ktorom rozpoznala príležitost' oslobodenia od nevyhnutnosti a hermeneuticky chápanú politickost'. Ako postrehla S. Benhabib (1996: 77-79), v kontexte celoživotného diela Arendtovej sa vyskytujú dve verzie verejného (public space): raz ako priestor sút'aže (predvádzanie pred inými svojich cností a morálnej prevahy), druhý raz $\mathrm{v}$ asociatívnej verzii, a tá je stále inšpirujúca. V nej Heideggerovu analýzu starostí človeka o svoje bytie rozšrírila na záležitosti verejného života tak, že l'udia podmienenost' svojho spoločného bytia berú ako „starosti o to, čo bude“. Riešia ich prostredníctvom reči

\footnotetext{
3 Arendtová slovom verejný označuje dva fenomény, úzko navzájom späté, ale nie identické: „vše, co se ukazuje před obecenstvem, vše, co může každý vidět a slyšet“ (2009: 66); „Za druhé slovo „veřejný“ označuje svět sám, nakolik je právě svět tím, co nám je společné (kurzíva - J.S.), a jako takový se odlišuje od toho, co nám patř́ jako soukromé.“ (2009: 69).
} 
a persuázie, hl'adajú porozumenie a zhodu, ako spoločne konat', a práve na to kládla vel'ký dôraz.

Ponechám bokom mnohé kritikou ${ }^{4}$ odmietnuté stránky jej koncepcie, aby som upriamil pozornost' na momenty, ktoré sotva možno obíst' pri aktualizovaní pojmového aparátu: spoločnému konaniu pripisuje vytváranie „nehmatatelných a vždy nanejvýš křehkých vztahů mezi lidmi, jenž nelze věcně ukotvit“ (Arendtová 2009: 256). Okrem toho mu pripisuje charakter natality chápanej ako uvádzanie do života niečoho nového, čo je podla A. TonkliKomelovej (2012: 806) metaforou pre slobodnú politickú činnost'. Dovolím si navrhnút, aby sme jej opis rozdvojeného života $\mathrm{v}$ oikos a polis vyjadrili nie v zaužívanom ,public space“, ale ako charakteristiku dvoch prostredí. Pojem prostredia umožňuje lepšie odlíšit' premenlivé stránky reality spôsobené prienikom informačných technológií do verejného života spoločenstiev ${ }^{5}$.

Už predtým, v dikcii poznačenej sporom o povahe verejnosti, v ktorom W. Lippmann (The Phantom of Public 1925) varoval pred jej iracionalitou, John Dewey v diele Public and Its Problems (1927) - čoby advokát prínosu verejnosti pre chod demokracie - si pre jej vymedzenie zvolil analýzu l'udského konania. Vychádzal z faktu dvojakých dôsledkov transakcií medzi l'ud'mi. Tie z nich, ktoré dopadajú na nezainteresovaných - sú verejnou záležitostou: „Verejnost' pozostáva zo všetkých tých, čo sú ovplyvnení nepriamymi dôsledkami stykov do tej miery, že sa považuje za nevyhnutné, aby sa o tieto dôsledky systematicky dbalo“ (Dewey 2001: 57), a preto „dotknutí“" podnikajú kroky na ochranu svojich záujmov. Podobne ako Tönnies i Dewey zdôraznil časovú a priestorovú variabilitu verejnosti: „fakt, že verejnost' závisí od dôsledkov konania a od vnímania týchto dôsledkov", spôsobuje, že „Nikdy a nikde nenájdeme verejnost’, ktorá by bola rovnaká.“ (Tamže: 69). Pravda, v modernej komplexnej spoločnosti je pod vplyvom globalizácie t’ažko rozoznat', odkial' napr. škodlivé dôsledky pochádzajú a kto je ich pôvodcom. Calhoun (2013: 93) postrehol, že Dewey neposkytuje žiadnu odpoved' na otázku, ako sa pasívna množina „dotknutých“" premení na aktívnu verejnost'. Ale na rozdiel od idealizujúcich koncepcií Arendtovej i Habermasa verejnost' vnímal ako odpoved' na reálne problémy života spoločenstva (Calhoun 2013: 69) a anticipoval ju ako činitel’a spontánnych pohybov zdola - osôb nevykonávajúcich moc.

\footnotetext{
${ }^{4} \mathrm{Z}$ množstva kritických rozborov jej diela odporúčam do pozornosti skvelé štúdie autorov, ktorí sa venujú teórii verejnosti a demokracie, pričom sa o ne sám opieram: C. Calhoun (2013), S. Splichal (2012), P. Gümplová (2007 a 2008), S. Benhabib (1996), J. Butler (2016), Ch. Mouffe (2015), J. Vargovčíková (2012).

5 Prednostne používam termín spoločenstvo, pretože ako dôvodí P. Rybicki (1979:162 nasl.), má vol’nejšie konotácie (vyjadruje rozmer od lokálneho po národné či až po úniu štátov). Rozumie sa ním spolužitie l'udí, ktorí nie sú náhodným agregátom jednotlivcov, pretože tí sú v ňom previazaní spoločnou kultúrou, vzájomnými kontaktmi, vzt’ahmi a zvykmi. Ich spolužitie sa vyznačuje určitou zjednocujúcou organizáciou ich života, pričom toto všetko sa opiera o dané materiálne podmienky. Tým sa nezriekam použitia termínu komplexná spoločnost' (vo význame Nation - State), čoraz viac integrovanej do štruktúr globálneho sveta.
} 
Myšlienkovo vplyvnou sa stala konceptualizácia Jürgena Habermasa, ktorou poznačil diskusie na celé desatročia. Ide o dielo Strukturwandel der Öffentlichkeit s podtitulom Untersuchungen zu einer Kategorie der Bürgerlichen Gesellschaft (1962). V ňom preskúmal vývoj „verejného života“ spoločnosti a jeho model predstavil ako historický fenomén. Pritom mu ako východisko poslúžil ideál pomerov, ked' sa od prelomu 17. a 18. storočia pretvárala sociálna štruktúra kapitalizmu a kultúrne milieu. Inšpirovali ho debaty súkromných osôb v literárnych kluboch, salónoch a osvetových spolkoch vo vel'kých mestách. Tie sa postupne stali permanentnými a neskôr sa rozrástli o „záležitosti spoločného života“, až napokon vyústili do kritiky mocenských pomerov. Z tejto perspektívy vyzval po vyhodnotení pomerov povojnového Nemecka (1945) k obnove öffentlichkeit - emancipačného projektu racionálne - kritickej diskusie. Spájal s ňou možnost' identifikovat' verejné dobro ako priesečník osohu tak pre jednotlivcov, ako i pre celú spoločnost'. Diskurzívne poňatie verejnosti a uplatňovanie komunikatívnej racionality sa mali stat' protiváhou inštrumentálnej racionalite systému (Gümplová 2007: 288). J. B. Thompson (2004: 206) docenil dodnes prít’ažlivé úsilie Habermasa kriticky poukázat' na etické vyprázdňovanie verejného života. Zároveň jeho filozoficky prepracovaný model praktického diskurzu kritizuje: „...je založeno na prostorové zakotvenosti a dialogičnosti... Dnes může jednáni ovlivnit lidi, kteři jsou značné rozptýleni $\mathrm{v}$ čase a prostoru - média vytvořila takovou podobu komunikace, jejiž součástí není dialogický hovor odehrávající se na jednom místě.“ (Tamže: 207).

Avšak tam, kde Dewey videl verejnost' ako reakciu na problematickú situáciu života „dotknutých“, Habermas identifikoval viac či menej unitárnu zónu öffentlichkeit (nadnesene nazývanou verejnou sférou) - nachádzajúcu sa medzi občianskou spoločnost'ou a štátom, zakotvenú v prvej a zameranú na ten druhý (Calhoun 2013: 24). Habermas bol síce historicky konkrétnejší, ale fungovanie öffentlichkeit naprojektoval jednostranne: viac $\mathrm{z}$ hl'adiska racionálneho posudzovania priebežného diania l'ud'mi, ale bez účasti emócií, vášní a túžob v ich konaní a bez kultúrnej produkcie, ktorá kritické momenty vtedajšej situácie stvárňovala na báze estetického cítenia. Habermas neprihliadol na neodvratné ovládanie takej zóny záujmovým hegemónom a súperenie „dotknutých“ s ním. Okrem týchto neudržatel'ných momentov vlna kritiky ${ }^{6}$ spochybňovala i preceňovanú možnost' dosahovania racionálneho konsenzu cestou verejnej debaty ako postačujúceho mechanizmu.

\footnotetext{
${ }^{6}$ Rozsah kritiky, akú jeho konceptualizácia vyvolala, je impozantný, ide možno o tisíce kníh a článkov a stále sa objavujú nové. Z novších pozícií, aké som využil, uvádzam: Jeffrey C. Alexander (2010), Hans J. Kleinstüber (2001), Craig Calhoun (2013), John B. Thompson (2004), Nancy Fraserová (2007), Petra Gümplová (2007), Samuel. Mateus (2011), Estelle Ferrarese (2015), Slavko Splichal (2012 a 2017) a Urbinati (2018).
} 
$\mathrm{K}$ tomu sa pridružila patália s prekladom öffentlichkeit do iných jazykov, lebo ide o pojem, ktorý má v nemčine viacero významov. Jeho bohatý obsah prekladatelia do angličtiny zúžili konfúznym výrazom „,public sphere“, čím vniesli doň priestorový rozmer a „prehĺbili pojmový zmätok“ (Livingstone 2005: 20). Termín sphere sa často používa v pôvodnej verzii Habermasovej knihy, ale rozhodne nie je náhradou za öffentlichkeit (Kleinstüber 2001: 97; Warner 2002: 47; Strum 1994: 161). Je kuriózne ${ }^{7}$, že v akademickom diskurze sa $\mathrm{z}$ nevydareného prekladu öffentlichkeit stala módna téma, pričom tento koncept „oddelili od verejnosti ako najdôležitejšieho aktéra pri vytváraní verejnej sféry“ (Splichal 2012: 67). Hoci sa Habermas v článku Futher reflections od takého nedorozumenia dištancoval, (Habermas 1992/1996:446), niektorí autori a prekladatelia doposial' zotrvávajú pri zavádzajúcom preklade „public sphere“ namiesto „publicness“. V zápalistom príspevku Jodi Deanovej preto vyzvala teoretikov, „aby hodili přez palubu myšlenku veřejné sféry“ (2004: 198) v pokryvenom chápaní.

V najmenšej možnej skratke som pripomenul kl'účové prvky významných autorov ${ }^{8}$ minulosti, ktoré sprevádza čaro inšpirácie, takže by nemali chýbat' pri pokusoch o rekonštrukciu chápania verejnosti odpovedajúceho digitálne pozmenenej súčasnosti. Sotva sa možno zriect' Habermasom uplatňovaného historicko-sociálneho určenia verejnosti a zakomponovania do jej konceptualizácie kl'účového fenoménu komunikácie. Rovnako sa nezaobídeme bez Arendtovej zdôraznenia povahy moci prameniacej z potenciálnej „súhry konajúcich" či kultúrneho zakotvenia problematiky. Ani v súčasne prebiehajúcej digitálnej transformácii nemožno pustit' zo zretel’a Deweyvo usmernenie, že verejnost' má organické spojivo s praktickými problémami života spoločenstva. Rovnako sa treba vyrovnat' s poukázaním Fraserovej, že problematiku verejnosti už nestačí viazat' na občianstvo (prakticky ani teoreticky), ale na l'udskú bytost'. Toho sa v štúdii pridržiavam.

$\mathrm{K}$ dedičstvu konceptualizácie možno priradit' poňatie verejnosti Carla Schmidta ${ }^{9}$ dvadsiatych rokov 20. storočia, ako aj výpovede W. Millsa o stave verejnosti v diele Mocenská elita (1956), rovnako aj kritické poznámky na jej adresu od R. Sennetta v obšírnej štúdii The Fall of Public Man (1974). Ich práce však majú len diagnostický charakter a rovnako ako predtým citovaní autori riešili tému verejnosti ako komplikáciu života vyvolanú fakticitou masovej spoločnosti a vplyvom masmédí́. Podl'ahli presvedčeniu o úpadku

\footnotetext{
7 Ako uvádza Kleinstüber, prekladatelia Habermasa (Sara Lennox a Frank Lennox) zaviedli pojem verejná sféra v prvom článku v New German Critique v roku 1974 No. 3 bez toho, aby si uvedomili d'alekosiahle dôsledky svojho rozhodnutia, a tým otvorili cestu priživovania sa epigónov na kvázi novej téme.

${ }^{8}$ Celý rad iných konceptualizácií a ideových koreňov riešenia problematiky od čias osvietenstva tu nemôžem opisovat', čitatel’a odkazujem na mnou citovanú literatúru i svoje štúdie (Stena 2016a: 109-133).

9 Píše o tom Nadia Urbinati (2018: 246-253).
} 
verejnosti, boli svedkami oživenia sociálnych hnutí (k nim patrí A. Touraine), ale konceptuálne problematiku neriešili.

V istom zmysle ku konceptuálnemu dedičstvu možno zaradit' aj texty autorov, ktorí vo verejnosti videli (občas stotožnenej s davom či s verejnou mienkou) nebezpečný fantóm, ohrozenie demokracie, nositela konformity a spájali ju so spoločenskou nivelizáciou, alebo ju považovali za subjekt poddávajúci sa simulakrom (J. Bentham, A. de Tocqueville, S. Kierkegaard, G. Le Bon, W. Lippmann, J. Ortega Y Gasset, R. E. Park, H. Blumer, D. Riesman, J. Baudrillard).

V 90. rokoch 20. storočia sa situácia $\mathrm{v}$ reflektovaní problematiky verejného života zásadne mení pod vplyvom (ambivalentných) dôsledkov globalizácie a nástupu tzv. nových médií. Najprv Fraserová, reflektujúc realitu globalizácie, hlboko kriticky posudzuje predpoklady prijaté v koncepte Habermasa. Zdôvodnila, že tzv. „public sphere“ treba považovat' za oblast' pluralizovanú, hierarchizovanú a konfliktnú. Odmietla jeho myšlienkový rámec vestfálskeho typu pomerov, $\mathrm{v}$ ktorých ohniskom záujmu verejnosti sú pomery v kompetencii národného štátu. Ten pod vplyvom globalizácie, ked' sa zmenilo mocenské pole, už nie je schopné garantovat' dopady ekonomických a politických procesov na podmienky života svojich občanov. Prišla s návrhom rozlišovat' „slabé“ a „silné“ (hegemonické) verejnosti a v súvislosti s tým zaviedla do obehu dva nové pojmy - kritériá normatívnej legitimity a politickej úćinnosti pôsobenia verejnosti (Fraserová 2007: 114-144). Zároveň vyzvala teóriu verejnosti zrekonštruovat' a repolitizovat' (tamže: 117).

\section{Dialektika verejného: realita a pojmy $\mathbf{v}$ pohybe}

Diskusiu o štrukturálnych premenách a funkčných aspektoch verejného života sotva možno úspešne viest' bez rešpektovania historickej podmienenosti a vývoja tak samej reality, ako i pojmového aparátu, ktorým sa jej zmocňujeme. To si vyžaduje zohl'adnit' genealógiu pojmov, osobitosti a tradície ich ukotvenia v sémantickom poli rozdielnych jazykových milieu a vyvarovat' sa splývania terminológie pod vplyvom publicistiky a hovorovej praxe. Tieto nároky sa odrážajú v doteraz prebiehajúcich diskusiách zacielených na vyrovnanie sa $\mathrm{s}$ konceptualizáciou Habermasa (Thompson 2004; Kleinstüber 2001; Kahn Kellner 2009; Mahony et al. 2010; Gripsrud et al. 2010; Strani 2014; Ferrarese 2015), pravda, z pozícií odlišných paradigiem. Podobná rozmanitost' sprevádza aj inovatívne konceptuálne riešenia, ktoré zohl'adňujú dopad digitálnych technológií na tvárnost' 'verejného' (Mateus 2011; Splichal 2012; Enjolras Steen-Johnsen 2017; Ettinger 2018). Z pohl'adu morfogenézy by sa mal objavit' odlišný obraz toho, čo bolo považované za tzv. verejnú sféru.

Väčšina súčasných akademických diskusií prekonáva nazeravo-zmyslové poznanie, ako i stav, ked' chápanie 'verejného' uviazlo bud' v dichotomickom 
strihu, alebo je vnímané esencialisticky a v nemenných formách. V tejto štúdii sa zriekam strnulého vyčleňovania sfér a ked’že tradovanú tzv. vel'kú dichotómiu privátne/verejné (ako ju nazval Bobio 1989) Meyrowitz odmietol ${ }^{10}$, navrhujem ju nahradit' predstavou kontinua, kde medzi jeho krajné póly sa

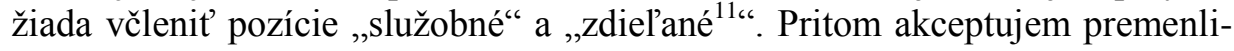
vost' hraníc medzi nimi a ich priepustnost'. Všetky štyri prvky takého kontinua sa navzájom odlišujú pradivom sociálnych väzieb (t. j. závislost’ami, sociálnymi vzt’ahmi a osobitným étosom). Najviditel'nejším - nie však jediným príznakom ich rozlišovania je rozdielny pomer participácie a vylúčenia: to, čo považujeme za súkromné, je založené na vyradení z participácie ostatných príslušníkov spoločenstva, ktoré tento stav legitimizuje. Blízky tomuto pólu je okruh väzieb označených ako služobné. V ňom sa uplatňuje striktná deliaca čiara medzi inštitucionalizovanými predpismi či rolami poverených osôb $\mathrm{v}$ pomere k ostatným príslušníkom spoločenstva (napr. lekár verzus pacient). To, čo som označil ako ,zdiel'ané", priamo nevylučuje ostatných príslušníkov spoločenstva, ale ich participáciu ohraničuje (rôzne platformy tzv. zdiel'anej ekonomiky). Napokon pozícia „verejné“ je jediným prvkom kontinua, pri ktorom - normatívne vylúčenie neprichádza vôbec do úvahy, lebo sa vzt’ahuje na kohokol'vek $z$ daného spoločenstva, zato predpokladá špecifickú väzbu medzi zúčastnenými.

Ako východisko pre vymedzenie pojmu „verejné“ mi poslúži návrh N. Fraserovej, v ktorom uviedla: „Veřejné může znamenat 1) vztahující sa ke státu, 2) př́ístupné všem, 3) týkající se všech či 4) vztahující se k obecnému dobru a ke sdílenému zájmu. Každé z těchto definic odpovídá př́slušný protikladný smysl 'soukromého', přičemž 'soukromé' nabývá ještě dalších dvou významů, které není těžké uhodnout: 5) vztahující se k soukromému vlastníctví v tržní ekonomice a 6) vztahující se k intímnímu domácímu či osobnímu životu, včetně života sexuálního.“ (Fraserová 2007: 96). Toto taxonomické vymedzenie „verejného“ (prekračujúce dichotómiu) nás len uvádza do problematiky, ktorú v nových historických súvislostiach sa viacerí autori opätovne pokúšajú hlbšie sociologicky preskúmat'.

V tejto štúdii odhliadnem od prípadov, ked' status 'verejného' jednorázovo ustanovuje autorita (napr. štát, cirkev, cudzia moc) a zameriam sa len na spôsoby jeho kreovania zdola $\mathrm{v}$ každodennom živote spoločenstva. Ked' sa niečo $\mathrm{z}$ bežného diania $\mathrm{v}$ ňom alebo $\mathrm{v}$ živote jeho príslušníkov stáva verejným ( $\mathrm{k}$ mechanizmu, akým sa to odohráva, sa vrátim), znamená to, že nadobudlo

\footnotetext{
10 „Dichotomie veřejného proti soukromému je tak př́liš zjednodušijíci, než aby mohla popsat dopad elektronických médií. Televize se totiž zmocňuje událostí, které již mají veřejný charakter, a činí je ještě veřejnejšími.“ (Meyrowitz 2006: 235).

11 Pre prvok „zdiel'ané“ v naznačenom zmysle t’ažko nájst' vhodný termín v našom jazyku. Nazvat' ho „komunitným“ nevystihuje jadro veci. Ked’že nejde iba o vlastníctvo, ale aj o zvyky, záujmy a zmýšl’anie vlastné vyhranenému okruhu osôb, $\mathrm{v}$ modernom svete to nemusí byt' zviazané s lokalitou. V praktickom živote sa v súčasnosti rozmáha zdiel'anie áut, bicyklov a bytov, čo predstavuje osobitný status, nie je to ani „spoločné“ ani „,verejné“ (v zmysle, ako to uvádzam), ale zdiel’ané.
} 
ontologicky novú kvalitu. Také „niečo“ sa stáva dôležitou záležitost'ou pre spoločenstvo, dostupnou pozornosti pre kohokol'vek z jeho príslušníkov. Tí takúto záležitost' zohl'adňujú vo svojom horizonte zmýšl'ania, pod jej vplyvom korigujú svoje postoje, ba i praktické konanie, a tým nadobúda status nadindividuálneho fenoménu. Tento moment privlastňovania sociálnym celkom pripomína aj S. Mateus (2011: 282). Pravda, nie všetko, čo sa ponúka do pozornosti ostatným, nadobudne status verejného, ak to nie je spoločensky relevantné alebo z iného dôvodu nimi významovo akceptované.

Kritický realizmus ako filozofické východisko morfogenetického prístupu vedie sociológa $\mathrm{k}$ tomu, aby sa zameral na analýzu podmienok (nielen fenomenologickú stránku), ktoré umožňujú vysvetlit' výskyt a určit' príčinné sily skúmaného sociálneho javu. V prípade témy 'verejného' - ako to ukázali súčasní autori - za nevyhnutnú podmienku sa považuje špecifická <kvalita sociálneho prostredia> spočívajúca vudržiavaní nehatenej komunikácie v spoločenstve (ked' je možné vidiet', počut', čítat' o záležitostiach spoločného záujmu, a tiež mat' prístup $\mathrm{k}$ vyjadreniu vlastného názoru) $\mathrm{v}$ jednote $\mathrm{s}$ udržiavaním viditel'nosti (visibility). V nemeckom jazyku pre označenie takej kvality prostredia sa zaužívala terminologická zloženina „öffentlichkeit“ a podobne aj v angličtine - „publicness“; v jazyku slovenskom ani v českom nemáme adekvátny terminologický ekvivalent. Navrhujem ju pomenovat' použitím príslovkového určenia - ako ho odporúča i Mateus (2011) - termínom <proverejne $>^{\mathbf{1 2}}$, kým sa neobjaví vhodnejší názov. Pravda, toto riešenie prináša mierny významový posun oproti vymedzeniam Habermasa, ale zdá sa byt' produktívnejšie $\mathrm{v}$ čase digitálnej transformácie. Mali by sme tým rozumiet' sociálnu kvalitu prostredia, ked' možnosti podiel'at' sa v rozmanitých podobách na verejnom dianí sú inštitucionálne zabezpečené (občianske práva, vláda práva) a zo strany jednotlivcov je prítomná ochota a pripravenost' $\mathrm{k}$ účasti. Pochopitel'ne, kvalita <pro-verejne> sa v dejinnom vývine manifestuje vždy $\mathrm{v}$ inom formáte $\mathrm{v}$ dôsledku spoločenských zmien sprevádzaných premenami sociálnej komunikácie, ako aj metamorfózami viditel’nosti. Pozrime sa na to detailnejšie.

ZÁRODKY. Rozpoznávanie začnem pomermi krest’anského stredoveku (odhliadajúc od populárnych analógií so starogréckym polis). Vtedajšie usporiadanie života spoločenstiev bolo dané suverenitou moci vládcu a jemu podriadeného správneho aparátu, pričom duchovný poriadok a kultúra boli $\mathrm{v}$ rukách cirkvi. $\mathrm{V}$ týchto pomeroch sa dôsledne odlišovalo súkromie od verejného diania, taká separácia našla oporu aj v rozčlenení rímskeho práva. Až do vynálezu tlače verejná komunikácia prebiehala bezprostredne a jednosmerne

12 Slovník slovenského jazyka takýto výraz neobsahuje, ale zato akceptuje výraz „prosociálny“. 
(rozhodnutia vrchnosti adresované l'udu na zhromaždení), verejnými boli oslavy nariadené či povolené vrchnost'ou, cirkevné omše a slávnosti, pranierovanie a popravy odsúdených, jarmoky, ale nič iné z uplatňovania moci panovníka nebolo viditel’né. Výraz „verejné“ slúžil ako atribútové určenie toho, čo presahovalo okruh súkromia a vyjadrovalo stav alebo status vecí, záležitostí či vzt’ahov - nemecky öffentlich, anglicky publicly, francúzsky publique. Pojem „verejnost““ v zmysle substantíva sa nepoužíval, nebolo čo ním označit'. Ani Kant vo svojom osvietenskom texte nepísal o verejnosti (ako to nepresne prekladajú), ale o verejnom použití rozumu ${ }^{13}$. Ceremónie panovníka a jeho dvora pred zhromaždenými poddanými (v roli publika) Habermas označil ako „verejnú reprezentáciu panstva“ a nepovažoval ju za oblast' sociálna, ale za atribút statusu (Habermas 2000: 61). Teda išlo o prívlastkové určenie, deskripciu <dobovej kvality prostredia>. Ústretovost' l'udí $\mathrm{k}$ verejnému, komunikácia o záležitostiach spoločného života a viditel’nost' (bola individualizovaná a bez synchronizácie) bola predurčená vôlou panovníka, resp. cirkvi. Sporadické vzbury a rebélie poddaného l’udu boli lokálne a nepredchádzala im názorová výmena, akú $\mathrm{v}$ neskoršej dobe obstarala práve verejnost'. V danom prostredí sa publicita spočiatku praktizovala vo forme ústneho podania (úlohu verejnej mienky zohrávalo klebetenie), v podobe kázní alebo rukopisných dokumentov o živote svätcov, až neskôr aj tlačovinami. Už vydávanie almanachov, ako uvádza Lohisse (2003: 118) viedlo k prebudeniu svetského informovania. Kým spočiatku dominujúcou technológiou komunikácie boli reč (konverzácia), písmo (osobná korešpondencia a rukopisy), rozmachom kníhtlače vznikli predpoklady pre šírenie ideí renesancie a osvietenstva.

VZNIK. Načrtnutá realita verejného života (pravda, vykreslená simplifikujúco) - ani v dôsledku historických premien opísaných J. Habermasom - v novo sa vynárajúcej konštelácii úplne nezaniká, ostáva pôdou pre vynorenie jeho novej tvárnosti. Etablujúca sa trieda podnikatel'ov presadila do služieb praktického života objavy prírodných vied, technické vynálezy a ideály osvietenstva (Deklarácia práv človeka a občana 1789). Došlo k uvol'neniu l’udí z pút nevol'níctva, $\mathrm{k}$ presadeniu efektívnejšieho modelu hospodárenia a sformovaniu kultúry civility. Sociálna komunikácia dostala nové krídla: najprv vznikom a šírením tlačovín, potom zavedením telegrafu (1739), telefónie (1849) a spravodajských agentúr. $Z$,pevniny“ opúšt’aných pomerov ako dôsledok uvedených premien - podl'a logiky procesu morfogenézy - sa vynára ontologicky nová vrstva reality verejného života $\mathrm{s}$ novými (odlišnými od pôvodných) vlastnost'ami a príčinnými silami. Spomeniem len zásadné: l'ud postupne uznali za prameň moci (a nie božiu vôlu), občania nadobudli právo vyjadrovat' sa

\footnotetext{
13 „Ich verstehe aber unter dem öffentlichen Gebrauche seiner eigenen Vernunft denjenigen, den jemand als Gelehrter von ihr vor dem ganzen Publikum der Leserwelt macht.“ I. Kant Was ist Aufklärung? 1784.
} 
$\mathrm{k}$ rozhodnutiam vládnych štruktúr, čo zmenilo spôsob legitimizovania politickej moci. V mentalite tried nastupujúcich na historickú scénu sa presadila racionalita a v sociabilite popri kooperácií $\mathrm{v}$ hospodárstve sa rozvíjalo spolčovanie na občianskej báze. Práve to, takpovediac, postavilo viditel'nost' na vlastné nohy: stala sa autonómnou a vd'aka sprostredkujúcej funkcii médií sa začala obohacovat' o neosobné prvky ${ }^{14}$. Pre takto pozmenené spoločenské (ekonomické, politické, kultúrne) podmienky sprevádzané premenou viditel'nosti a sociálnej komunikácie Habermas uplatnil pojem ${ }^{15}$ Die Öffentlichkeit. Všimnút' si treba, že autor normatívnost' pripísal tejto <kvalite prostredia $>$ v spoločenstve a nie subjektovému aspektu verejnosti, k objasneniu ktorého môj návrh konceptualizácie smeruje.

V týchto historických podmienkach sa $\mathrm{v}$ konštitúcii spoločenstva objavila spomínaná $<$ kvalita prostredia $>$, ktoré umožnilo etablovanie sa verejnosti $\mathrm{v}$ jej subjektovom určení ako svojbytného sociálneho činitel'a s potenciálom účinkovat' ako autonómna agencia ${ }^{16}$ zasahujúca do jeho diania a vývoja. Zdôrazňujem, že táto kvalita nepredstavuje ustálenú celospoločenskú verejnú komunikačnú sféru, ako ju Habermas vymedzil vo svojom skoršom diele. Svedčia o tom vyjadrenia samotného autora v jeho zrelom diele Faktizität und Geltung (1992), ked’ napísal: „Die Öffentlichkeit nemožno chápat’ ako inštitúciu a určite nie ako organizáciu. Nie je ani rámcom noriem s diferencovanými kompetenciami a rolami, predpismi o členstve atd'. Sotva tiež predstavuje systém; hoci umožňuje vyznačit' vnútorné hranice, navonok sa prejavuje otvorenost'ou, priepustnými a posúvatelnými horizontmi. »Die Öffentlichkeit« možno najlepšie opísat' ako siet' pre komunikovanie informácií a stanovísk, a teda mienok; toky komunikácie sú v tomto procese filtrované a syntetizované takým spôsobom, aby sa skomprimovali do zväzkov tematicky špecifikovaných stanovísk verejnej mienky." (Citujem nemecké vydanie ${ }^{17}$ z r. 1994: 435-436). O stránku d’alej uviedol: „Diese Öffentlichkeiten haften noch an den konkreten Schauplätzen eines anwesenden Publikums. ${ }^{18 ، “}$ (Tamže: 437). Z toho vyplýva, že Habermas öffentlichkeit primárne charakterizuje znakmi zal'udneného prostredia, a nie ako množinu osôb triviálne stotožňovaných s verejnost'ou.

\footnotetext{
14 Prvky, ktoré nevyplývajú z vlastných zmyslových zážitkov, k nim sa pribal'ujú napr. „podhodené“ významy vecí a udalostí.

15 Už pred Habermasom uvedený pojem pre túto problémovú oblast' používal Ernst Manheim v práci Die Träger der Öffentlichen Meinung. Studien zur Soziologie der Öffentlichkeit (1933).

16 Pojem „agency“ sa postupne udomácňuje i v našej odbornej spisbe: Černík a Viceník (2011: 88) píšu o agencii ako o schopnosti zapričiňovat' udalostí. Pojem vyjadruje dispozíciu vyvolávat' dôsledky (i nezámerné) a nie vždy sa musí viazat' na konanie l'udí. Príkladom sú infekčné epidémie, od ktorých sa odvíja ret’az sociálnych pohybov, niekedy s dopadom na oblast' politiky, ba i vzt’ahov medzi štátmi.

17 Nebolo možné sa spol'ahnút' ani na anglické vydanie Between Facts and Norms (1996), ani na pol'ský preklad Faktyczność i obowiązywanie (2005), pretože klúčový pojem öffentlichkeit prekladajú vágnym zvratom public sphere, resp. sfera publiczna, čo viacero kritikov jednoznačne odmietlo ako zavádzajúce.

18 Öffentlichkeiten sa stále viažu na konkrétne dejiská prítomných publik (kurzíva - J.S.).
} 
Zrod Öffentlichkeit - typu kvality sociálneho prostredia - je u Habermasa historicky spojený s buržoáznou vrstvou a vzdelaným meštianstvom. Každý následný typ kvality prostredia je okrem svojho historického rámcovania vždy empiricky zakorenený v sociálnej štruktúre spoločenstva i v jeho kultúre. Niektorí autori Öffentlichkeit terminologicky aktualizujú, ale jeho podstata ako vypestovaná kvalita sociálneho prostredia s emancipačným obsahom ostáva v platnosti. Príkladom môže poslúžit' pojem ,glasnost“" - sprievodný atribút tzv. perestrojky, o ktorú sa pokúsil M. S. Gorbačov v snahe skoncovat's tabuizovaním tém.

MASOVOSŤ. Ked' kapitalizmus upevnil svoje postavenie a d'alej rozvíjal svoj potenciál podriad'ovania si rôznych oblastí života spoločnosti, expandoval aj do oblasti sociálnej komunikácie. Súbežne v zápasoch o svoje práva rástla životná úroveň obyvatel'stva, rozšíril sa prístup k vzdelaniu, rozrástol sa fenomén vol’ného času a stúpla miera materiálnej spotreby. Sociológovia 20. storočia kriticky písali o masovej spoločnosti, masovej kultúre a zrode zvonku riadeného človeka (Riesman) či jednorozmerného človeka (Marcuse). Konzumovaná bola aj kultúra ako tovar s presilou zábavy, na čom bol zainteresovaný mediálny priemysel so svojimi korporátnymi záujmami, výdatne ,živený“ reklamou. Po masovom rozšírení televízie sa komunikácia zmenila. Dialogických foriem ubudlo, komunikačný proces sa stal prevažne jednosmerný. Masovost' pretvorila komunikáciu na prenos „téměř současně nést sdělení od jednoduchého zdroje k milionům osob" (Lohisse 2003: 143). Aj viditel'nost' nadobudla nový rozmer: povedla doslovného významu ako okamžitý zmyslový vnem (visual) vystupuje v širšom význame „ako všetko, čo nadobúda povahu súboru symbolických významov súvisiacich s konkrétnymi udalost’ami (čím sa stáva niečím, čoho sme si vedomí)" (Mateus 2014: 261). Doslova narkotizujúci vplyv na kvalitu prostredia otvorenosti mal zrod Public relations a expanzia marketingu (zacielených na vytváranie súhlasu a manipuláciu vedomia obyvatel'stva). Ich pôsobenie znemožnilo premenu nehatenej výmeny názorov „slobodných občanov“ na autentickú verejnú mienku, ako to v pomeroch liberálnej demokracie model Habermasa predpokladal, naopak, ovládli ju spomenuté sily. Od týchto pomerov odvinuli skepsu k možnostiam verejnej mienky W. Mills, R. Sennet, ale aj kritiku masovosti citovaní H. Arendtová a J. Habermas.

Úloha médií vo verejnom živote spoločnosti je bohato pokrytá odbornou literatúrou, takže vystačí len pripomenút' tézy dôležité pre riešenie problematiky tejto štúdie. Ide hlavne o schopnost' médií reorganizovat' rámce l'udských interakcií, ovplyvňovat' rozhodovanie l'udí, rozporuplné pretváranie obrazu reálneho sveta či dôsledky na ich sociálnu seba/identifikáciu. J. Meyrowitz poukázal na fakt, že médiá oslabili kedysi pevný vztah medzi fyzickým a 
sociálnym miestom, prelomili bariéry medzi súkromným a verejným, podkopali tradičné poňatie hierarchie a autority (2006: 136). J. B. Thompson upozornil na rozluku času a priestoru i vznik nových druhov interakcií (K tradičnému typu „face to face“ pribudli technikou sprostredkované interakcie umožňujúce dialóg či sprostredkované kváziinterakcie - tie sú monologické, masové, charakteristické šírením významov $\mathrm{z}$ jedného centra $\mathrm{k}$ bližšie nešpecifikovaným príjemcom bez toho, aby tí mohli na ne reagovat' a aby sa spätne ich správanie vyhodnocovalo). Masívne rozšírenie TV vysielania umožnilo, že diváci sa stali cestovatel'mi v priestore a čase, získavali informácie o udalostiach vzdialených ich životnej skúsenosti. Presadil sa trend rastu neosobných a sprostredkovaných interakcií, ked' „Lidé stále častěji získávají informace a symbolické obsahy spíše z jiných zdrojů než od lidí, s nimiž přímo přicházejí do styku ve svém každodenním životě.“" (Thompson 2004: 75) J. Deuze (2015: 201) pracuje s pojmom mediatizácia, pod čím rozumie podliehanie vplyvu médií, ked' napr. subjekty hospodárske, politické, vedecké či občianskej spoločnosti reagujú nie na skutkový stav, ale na obraz o nich utváraný médiami. V knihe Media life rieši otázku „Jak můžeme pojmout sami sebe a svět, ve kterém žijeme, jestliže přijmeme, byt' jen na okamžik, že nežijeme z médií, ale v médiích.“ (Tamže: 10).

Tieto vlastnosti a príčinné vplyvy vypovedajú o tom, že v podmienkach masovosti máme do činenia $\mathrm{s}$ ontologicky novou vrstvou reality verejného života, ked' pro-verejné sa stalo mediálne komodifikovaným prostredím.

DIGITALIZÁCIA. - V priebehu 90. rokov 20. storočia sa presadila jednak technologicko - komunikačná revolúcia založená na digitalizácii, ako aj globálna reštrukturalizácia kapitalizmu, tieto procesy nad’alej prebiehajú. Svet neprestal byt' masovým, ale ich účinky sa stali evidentné aj mimo okruhu euroamerickej civilizácie. Prejavili sa nástupom nových foriem mediálnej komunikácie, ale i v metamorfóze publicity a sociálnych interakcií. Nové formy komunikácie, mobility a združovania sa $\mathrm{v}$ dobe digitálnej transformácie ${ }^{19}$ prejavili i na meniacom sa dizajne verejnosti. Rekonštrukciu jej teórie už sotva možno úspešne odvinút' od kolektívneho správania alebo od neurčitej pozície pripísanej verejnosti teoretikmi občianskej spoločnosti. M. Castells upozornil na významnú úlohu vzniku sociálnych sietí na webe, ktoré vd’aka svojej autonómii - v situácii, ked' väššinu komunikačných kanálov zmonopolizovali korporácie a vlády - umožnili nadväzovat' väzby odporu a dožadovat' sa práva spolutvorit' históriu (Castells 2013: 14). V nadväznosti na nové komunikačné

\footnotetext{
19 Pre označenie aktuálne prebiehajúcich zmien G. Leonhard preferuje termín „digitálna transformácia“ (2018: 99), pretože idú nad rámec zmeny alebo inovácie. V zásade ide o proces metamorfózy (prirovnávajúc ju k pretvoreniu húsenice na motýl'a). Tá prinesie pokrok do všetkých oblastí života.
} 
podmienky treba vysvetlit', $\mathrm{v}$ čom teraz spočíva kvalita sociálneho prostredia označená ako <pro-verejne>.

Miniaturizácia elektronických zariadení a ich masová dostupnost' umožnili súčasným generáciám prežívat' symbiózu človek - stroj (počítač a zariadenia využívajúce digitalizáciu a siete), využívat' world wide web, mobilné pripojenie na telekomunikačné siete a webové služby (Facebook, Twitter, Linkedin, YouTube, Instagram, Wikipédia, Google). Prišli do styku aj s presadzovaním sa globalizovaného kapitalizmu platforiem, ktoré operujú v oblastiach ekonomickej, kultúrnej i politickej ${ }^{20}$. Pri nazeraní na „pro-verejné“ treba zohl'adnit' zásadné kvalitatívne informačno-technologické prezbrojenie a zosiet’ovanie. Jeho základom sa stalo digitálne kódovanie dát umožňujúce ich vizualizáciu, hybridizáciu prenášaného obsahu (text, zvuk, grafika), algoritmizácia a on-line komunikácia $\mathrm{v}$ reálnom čase, ako aj interaktívny styk s médiami. Na sociálnu komunikáciu mala vplyv konvergencia digitálnych médií s konvenčnými do komplexov, v ktorých nestrácajú svoju identitu. Zmenil sa i pomer medzi médiami a publikom: interaktívnost' umožnila pripojeným l'ud'om - eufemisticky povedané - spolurozhodovat' o ich obsahu; dokonca obohatit' mediálnu oblast' produkciou vlastných informačných obsahov (diskusné fóra, chatovanie, vlastné web stránky a pod.).

Technologické inovácie podmienili - zhodne s logikou procesu morfogenézy - vynorenie sa ontologicky novšej vrstvy reality verejného života, ktorá sa vyznačuje originálnymi vlastnost’ami a príčinnými silami. K jestvujúcim reálnym formám sociability pribudli komunikačnými technológiami sprostredkované sociálne vzt’ahy (napr. priatel'stvá na FB) a geograficky i telesne nezviazané komunity (napr. diskusné skupiny na internete). Osobám pripojeným na internet pribudli nové skupinové identity, ktoré spôsobujú moduláciu ich správania a nebývalé možnosti sebaprezentácie. Ocitli sa uprostred technológiou iniciovaných modalít skutočnosti (rozšírenej či výstižnejšie mediatizovanej reality ${ }^{21}$ ), ktoré asistujú pri formovaní pohnútok vystúpit', resp. zdržat' sa vystúpenia l'udí na verejnosti. K charakteristike vynorenej vrstvy verejného života patrí tiež kyberkultúra, chápaná radšej $\mathrm{v}$ antropologickom podaní, ako súčast' súčasnej l'udskej praxe. Zakorenená v materiálnych a iných podmienkach spoločnosti predstavuje súbor praktických zvyklostí, postojov, spôsobov uvažovania, hodnôt a narácií formovaný použivaním informačných technológí́ (Malina a kol. 2009: 138).

\footnotetext{
20 Bližšie o tom http://goldman.sk/home/kapitalizmus-platforiem/

21 Pojem „mediatizovaná realita“ výstižnejšie pomenúva konšteláciu, ked’ komunikačné obsahy obohatené o mixáže rozšírenej a virtualizovanej reality, s ktorými l’udia pripojení na siete prichádzajú do styku. Pravda, ovplyvňujú ich len potial', pokial' pozmenia ich vnímanie sveta. Krajným prípadom toho je fenomén imerzie - ide o mentálny stav hlbokého vnorenia sa do umelého sveta, ked’ v interakcii s ním je vlastné ,ja“ potlačené, alebo sa vytráca.
} 
V podmienkach masového využívania internetu vo svete kvalita sociálneho prostredia, vyjadrená pojmom <pro-verejne>, sa stala ovel'a komplexnejšou. Zahŕňa mediálne sprostredkovanú viditel'nost', je dostupná zdiel'aniu a širšie otvorenou spoločnému posúdeniu. Pri virtualizovanej konektivite tradovaná dichotómia verejné/súkromné nezanikla (Ettinger 201: 37), ale stratila explikačný potenciál. Potvrdzuje to analýza $\mathrm{S}$. Splichala prezentovaná v štúdii The (re)production of publicness and privateness in the liquid modern society (2017). V nej zaviedol dva nové pojmy opisujúce situácie $v$ oboch doménach tie sa nerozlučne splietli - a nových ciest, ktoré vedú k produkcii či „,verejného“ alebo „súkromného“ v rámci - ako on píše - integrovanej verejnosúkromnej komunikačnej siete ${ }^{22}$. Prikláňam sa $\mathrm{k}$ jeho riešeniam, lebo rešpektuje rozlíšenie subjektovej stránky verejnosti i aspekt prostredia (jeho kvality). Navyše prihliada k otázkam práva na súkromie i $\mathrm{k}$ nárokom na reprodukciu a ochranu „verejného“ zaznávaných ideológiou neoliberalizmu. Aby som jeho uvažovanie o prvkoch novej reality, ktoré nemožno kategorizovat' ani ako verejné či ne-verejné, približil čitatel’om ponúkam túto schému.

\begin{tabular}{llll}
\hline Doména & Oblast' & Agencia & Stav/Kvalita \\
\hline Súkromného & $\begin{array}{l}\text { Súkromie osôb } \\
\text { (Personal Privacy) }\end{array}$ & $\begin{array}{l}\text { Zastieranie digitálnej identity } \\
\text { (Privacity) }\end{array}$ & $\begin{array}{l}\text { Poriadok uchovania } \\
\text { skrytosti } \\
\text { (Privateness) }\end{array}$ \\
Verejného & $\begin{array}{l}\text { Osobná kvázi } \\
\text { verejnost' } \\
\text { (Publicy) }\end{array}$ & $\begin{array}{l}\text { Zverejňovanie } \\
\text { (Publicity) }\end{array}$ & $\begin{array}{l}\text { Poriadok komunikačnej } \\
\text { otvorenosti } \\
\text { (Publicness) }\end{array}$ \\
\hline
\end{tabular}

V konštelácii presadzovania sa agregácie súkromnej a verejnej komunikácie Splichal popri tradičnom pojme „osobné súkromie“ (Privacy) - čo je oblast chránená právom na súkromie (a v súčasnosti ohrozovaná komerciou a marketingom) - zaviedol v doméne verejného ako náprotivok nový pojem „osobná kvázi verejnost“" (Publicy). Tá je utváraná jednotlivcom, ked’ povolil, alebo pozval iných l'udí, aby sa zapojili do „komunity“, ktorú(é) on/ona založil/a online. Je to špecifický doplnok k súkromiu l'udí, ktorých Bauman označil ako množinu osamelých, ktorí nikdy nie sú sami, pretože sú vždy pripojení2 ${ }^{23}$. Špecifické pre nich sú sklony vyjadrovat' sa otvorenejšie, odvážnejšie a kritickejšie než na iných miestach verejného života $\mathrm{v}$ dôsledku uvol’nenia zábran, rozpustenej anonymity, domnelej neviditel'nosti, disociácie predstavivosti, znižovania váhy autority v on-line prostredí.

\footnotetext{
22 The integrated public-private communication networks (IPPCN). Autor prevzal termín „internetizácia“, ktorým označuje nielen interaktivitu globálnej komunikačnej infraštruktúry, ale aj sériu nových sociálnych a kultúrnych javov spochybnuujúcich tradičné hierarchie a hranice v spoločnosti. Integrované komunikácie dnes prepájajú komunikáciu $\mathrm{v}$ reálnom čase a v čase ne-reálnom, rozširujú osobné kontakty, prítomnost' a mobilitu na všetky zariadenia, ktoré má daná osoba k dispozícii, a vytvára tak IPPCN (Splichal 2017: 36).

${ }^{23}$ Bauman, Z. (2015) From privacy to publicity: the changing mode of being-in-theworld.
} 
Druhým novým pojmom od Splichala je „zastieranie digitálnej identity“ (Privacity), ide o aktivitu vyvíjanú zo strany autonómnych jednotlivcov so zámerom aktívne ochraňovat' svoje osobné súkromie. Jej pendantom $\mathrm{v}$ doméne verejného je všeobecne známe „Zverejňovanie faktov“ (Publicity) ako aktivita sledujúca bud' upútanie pozornosti na seba $\mathrm{v}$ sieti alebo $\mathrm{v}$ lepšom variante kritiku osôb či inštitúcií za nezákonné či nemorálne praktiky v každodennom živote spoločenstva. V jeho pojmosloví d’alej vystupuje pojem ,,poriadok uchovania skrytosti“ (Privateness), ktorým označuje kvalitu podmienok v spoločenstve priznávajúcich jedinečnost' a dôstojnost' každému svojmu príslušníkovi ako základom l'udskej prirodzenosti. Jeho náprotivkom je už spomínaný pojem „poriadok komunikačnej otvorenosti“ (Publicness) (Splichal 2017: 43-45).

Isteže, interakcie typu face-to-face $v$ realite rutinného života spoločenstiev nevymizli, ale postupne počtom ustupujú nárastu technologicky sprostredkovaných kontaktov. Evidujem i rozsiahly problém premien celej privátnej domény (zmobilnenie) vyvolaných digitálnymi technológiami, ktorý nie je predmetom tejto štúdie.

$\mathrm{K}$ charakteristike <pro-verejne> $\mathrm{v}$ tvare virtualizovanej konektivity prispela J. Dean. V často citovanej štúdiii ${ }^{24}$ odmietla ,ideál veřejné sféry (pretože - J.S.) neodpovídá problémům a politickým možnostem dnešního světa. Vnucuje nám nesprávnou diagnózu př́ítomnosti.“ (2004 - 2009). V jej koncepte (nazvala ho kybersalón - J.S.) upozornila na vyhladzovanie odlišností - dôležitého od nedôležitého, spol'ahlivého a nespol'ahlivého, zdôvodneného a povrchného, že v ňom všetko existuje vedl'a seba ,a souteží o popularitu“ (tamže: 218). Nastolila i problém adekvátneho vystihnutia subjektovosti, ked’že technologické možnosti dovol'ujú pohrávat' sa s vlastnou identitou (a vystavit' sa riziku jej premeny na objekt, ked' sa pre iných stáva potravou a tovarom) či manipulovat' s významom vecí, vzt’ahov a situácií (tamže: 219-220).

K potrebe revidovat' teóriu verejnosti sa prihlásil tiež Samuel Mateus, ktorý v štúdii (2011) prišiel dokonca s novou optikou. Poukazujúc na slabosti Habermasovej paradigmy, ktorú vníma ako prepolitizovanú a statickú - a na druhej strane - odmietajúc teóriou médií presadzovaný variant zužujúci verejnost' na publikum (Audience) (2011: 278), vytýčil tretiu cestu. Navrhol prejst' na sociologické uvažovanie, ktoré umožňuje v ére digitálnych riešení identifikovat' to, čo tu nazývame <pro-verejne> v tvare virtualizovanej konektivity (Mateus zachoval výraz mediated publicness). V štúdii Visibility regimes in mediatized publicness (2014) prispel detailnou analýzou jednej z avizovaných súvislostí „publicnes“, menovite rozborom viditel'nosti, resp. zviditel'ňovania (visibility). Digitalizácia a internet ju zásadným spôsobom transformovali: vyviazala sa $\mathrm{z}$ lokalizovaných a časových súradníc, deak-

\footnotetext{
${ }^{24}$ Cybersalons and Civil Society: Rethinking the Public Sphere in Transnational Technoculture. 2001, Public Culture 13(2). Text bol preložený do češtiny, z neho vychádzajú moje citácie.
} 
tualizovala sa požiadavka H. Arendtovej na bezprostrednú (spolu)prítomnost' a vzájomnú viditel’nost' účinkujúcich, ktorou definovala „verejné“ (2009: 66). Dnes už naživo možno sledovat' vzdialené udalosti a vracat' sa $k$ video záznamu i spätne ich vidiet' a prežívat'. Inými slovami, zmyslový zážitok je obohatený sprievodnými obsahmi symbolickej povahy, ktoré sa „nabalujú“ významami sedimentovanými vo vedomí osôb, ale i „nadprácou“ médií, ked' chcú upútat' pozornost' publika.

Takto chápaná viditel'nost' televízie alebo internetu je rozšírením vizuálnosti a komplikuje vzt’ahy medzi pozerajúcimi a videnými. Mateus píše o radikálnom kontraste „medzi viditel'nost'ou a neviditel'nost'ou, medzi tými, ktorí pozerajú a nie sú videní, a tými, ktorí nevidia a sú videní“ (tamže: 263). A pripomína, že „neviditel'nost“", utajovanie a tajomstvá posilňujú moc. Podliehame tomu, ked’že vd'aka viditel'nosti je transparentnost' doplnkom viery: veríme $\mathrm{v}$ to, čo vidíme, viditel'nost' je synonymom autenticity a bezprostrednosti (tamže: 260). Autor upozorňuje, že problém viditel'nosti sa skomplikoval, virtualizovaná konektivita vytvára nové formy neprehl'adnosti, hoci nie sú ustanovené ako tajomstvo, aké patrí $\mathrm{k}$ vládnutiu. Demonštruje to na štyroch režimoch viditel'nosti a na príkladoch z politickej praxe naznačuje riziká a využívanie tohto javu. Netreba to rozvádzat', lebo v tejto štúdii bolo dôležité rozpoznat' spojitost' viditel'nosti s tým, čo nazývam <pro-verejne>.

Pokúsim sa zhrnút', čím je táto - našim zmyslom vo svojej totalite nedostupná - realita <pro-verejne>? Je to stav spoločenstva (príp. jeho časti), kde sa utvorila kolektívna citlivost' (Mateus 2017: 115) k problémom bežného spoločného života, $\mathrm{k}$ jeho rizikám a ohrozeniam. J. Butler považuje citlivost' $\mathrm{k}$ dianiu za „funkciu otvorenia sa k svetu, ktorý nie je možné plne poznat' ani kontrolovat"“ (2016: 130), je konsekvenciou „byt' otvoreným“. Vd’aka nej sa podl'a C. Calhouna utvára dočasná súvzt'ažnost' medzi príslušníkmi spoločenstva, osobitná forma integrácie alebo sociálnej solidarity povedla tých identít, akými disponujú z titulu svojej sociálnej (príbuzenstvo, priatel'stvá, susedia), národnej či štátnej identity (Calhoun 2013: 72). Práve na takú súvzt'ažnost' poukázal už G. Tarde (1901), ked' písal o vzájomnom a recipročnom vplyve odlišných myslí a vášní, ktoré sa prípadne môžu premieňat' na činy pri priestorovej a časovej vzdialenosti (Katz 2006: 271). Ked'že 〈pro-verejne> je systémová charakteristika, jednotlivec vystupuje v pozícii primárneho agensa (daný stav sa vzt'ahuje i na neho, ale ešte nie je aktérom). Kvalita <proverejne> neznamená celoplošné homogénne pokrytie spoločenstva, ako to predpokladá koncept Habermasa, a tiež nie stálost' v čase. Publicisticky vyjadrené, má svoje hĺbky i plytčiny, rovnako svoje vzopätia a obdobia ochabnutia. Tie sa odohrávajú vplyvom vývoja spoločenských a politických pomerov v spoločenstvách. Ukázalo sa, že <pro-verejne> prešlo radikálnymi 
premenami aj $\mathrm{v}$ dôsledku digitálnej transformácie (čo tiež sprevádza jeho volatilitu).

\section{K otázke substantívneho poňatia verejnosti}

Verejnost' je komplexný fenomén, pre myšlienkové uchopenie jeho aspektov sa používajú rôzne pojmy a s ním súvisiace koreláty - publicita, zverejňovanie (najmä citlivých firemných a vládnych dokumentov), verejná mienka, verejné priestranstvo, verejná debata). V tejto štúdii som načrtol atribútové určenie a rozviedol príslovkové, teraz možno prikročit' k substantívnej špecifikácii. Pre jej rozvinutie využijem poznávací postup navrhnutý M. S. Archerovou (1995: 165-170), ktorý nazvala „analytickým dualizmom“ (nie filozofickým). Ten umožňuje analyticky „odpárat“" subjekt a predmet od seba tak, aby sa ukázali ich odlišné vlastnosti a účinky ako dve odlišné stránky substantívneho poňatia, ktoré v zaužívanom pojme verejnost' bežne splývajú. I v bežnom živote sa verejnost' prejavuje vo dvoch modalitách.

Začnem s predmetnou stránkou, menej náročnou na vnímanie zmyslami človeka a empirické skúmanie. Na označenie lokalizácie publicity použijem názov verejné dejisko. Ide o sociálny útvar nadindividuálnej povahy (pripomínajúci koncept „gebilde“ L. von Wieseho), ktorý sa v teoretickom nazeraní vníma ako prechodné zahustenie zdiel'ania komunikovaných obsahov o iritujúcom probléme každodenného života medzi príslušníkmi spoločenstva, sprevádzané emotívnym zaangažovaním za jeho riešenie. Ako nadindividuálny sociálny útvar dejisko predstavuje dočasnú a spontánnu koncentráciu individualizovaných postojov, motivácií a symbolických operácií - pripísanie odlišných významov súvislostiam iritujúceho problému, odlišných od tých, aké reprezentuje záujmová protistrana. Teda nie je územne lokalizovaným miestom sociability, ale súvzt'ažnost’ou medzi osobami rôzne geograficky i sociálne situovanými, ako o nej písal citovaný C. Calhoun, ked' ju označil za osobitnú formu integrácie. Na tomto emotívno-kultúrnom pôdoryse sa rozvíja nadväzovanie kontaktov medzi „dotknutými“, v ňom sa odvíjajú komunikačné i praktické aktivity ako prejav svojrázneho zápasu (to čoskoro vysvetlím). Príkladom takého dejiska je verejná debata prebiehajúca $\mathrm{v}$ printových médiách či v TV, na internete alebo na verejnom priestranstve. Dejiskom je také združovanie osôb (nie vždy priestorové), ktorého účastníci sa spojili s intenciou poukázat' na problematické stránky spoločného života a $\mathrm{v}$ rámci občianskych práv sa dožadujú ich nápravy (nie pasívne sa prizerat' ako obecenstvo). Verejným dejiskom je i prípad, ked' sa niekto predvádza pred očami ostatných l'udí (hoc aj v digitálnom priestore), aby upútal pozornost' a dokáže vyvolat' medzi ostatnými pozornost'. Unikátny príklad publicity sa spája s menom Julian P. Assange, tvorcom portálu WikiLeaks. Dejiská - namieste je tu hovorit' o pluralite - sú rozmanité čo do formy (klasické viazané na tradičné médiá 
i online založené na webe), mnohé z nich boli predmetom vedeckých analýz (Šmídová-Matoušová 2012; Slavík - Pospěch 2019; Tubella 2004; Bierówka 2017).

V súčasnosti rozšírenú formu dejísk predstavuje internet a ním ponúkané služby (diskusné fóra, on-line sociálne siete a pod). Zásadne však platí, že dejisko sa utvára spontánne, nie je vopred daným útvarom (existujúcim či už objektívne alebo iba ako produkt úvah sociálneho konštruktivizmu), teda nemá podobu unitárnej medzisféry s falošnou uniformitou (Mateus), ktorú Habermas situoval medzi občanov a štát. V spoločenstve sa súbežne vyskytuje viacero dejísk, môžu svojím zameraním korešpondovat' alebo účinkovat' proti sebe (counter public). Objavujú sa príležitostne a v tomto zmysle predstavujú diskontinuitný rozmer verejnosti. $\mathrm{V}$ tejto ontickej rovine možno d’alej zaznamenat' charakteristiky dejiska, ako je množstvo zúčastnených osôb, frekvencia aktivít, počet miest výskytu, spôsoby manifestácie (od pokojnej po nátlakovú) a zapojenie mienkotvorných osobností. Posledné z uvedených znakov, v previazaní na vlastnosti verejnosti ako subjektu, sa podielajú na vzniku jej príčinných síl. Ktorá z kombinácií v tejto vnútornej väzbe je efektívnejšia, môže ukázat' len empirické skúmanie ich praktického výskytu.

$\mathrm{V}$ prípade druhej modality je predmetom analýzy subjektovost' verejnosti, ktorou sa odkrýva ontologická stránka skúmanej problematiky. Znova pripomínam, že verejnost'ou nie je arbitrárne označená množina l'udí (ako si to občas zjednodušujú samotní sociológovia ${ }^{25}$ ), ale je to materializácia vnútorného potenciálu výsostne sociálnej povahy, prítomná $\mathrm{v}$ každom integrovanom spoločenstve, ktorým sa udržiava kontinuita vplyvu zdola na pomery $\mathrm{v}$ ňom. Jeho podstatu nám pomohla odhalit' H. Arendtová, ked' poukázala na súvislost' verejnosti s prebúdzaním latentného potenciálu moci. Napísala: „Moc ale vlastně nemá nikdo, moc vzniká mezi lidmi, když společně jednají, a mizí, jakmile se tito lidé opět rozptýlí.“ (Arendtová 2009: 261). Pripomenula, že moc ako statok nejestvuje, moc vzniká medzi l'ud’mi pokial konajú s p o lo č n e. Subjektovost' verejnosti, prirodzene, neznamená ambíciu nahradit' legálnu moc, má však tendenciu počínanie delegovanej (či korporátnej) moci spochybnit', prípadne ju delegitimizovat'. Teda tajomstvo vplyvu príslušníkov spoločenstva na jeho celok spočíva v schopnosti jeho príslušníkov konat' spoločne (aktivizovat' kolektívnu „potentiu“ - E. Dussel (2008: 19), dočasne sa neformálne združovat' $\mathrm{s}$ ciel'om bud' spochybnit' súčasné pomery alebo podnety $\mathrm{k}$ ich zmene, odmietnut' prijaté riešenia mocenských orgánov, resp. korporátnych praktík či nastol’ovat' nové požiadavky. Spontánnu a kontingentnú aktualizáciu subjektovosti verejnosti konštatujú aj iní autori ako pôvodne G. Tarde (Mateus 2017: 117; Prodnik 2011: 276; Dolata - Schrape 2015: 5). Manifestuje sa

\footnotetext{
25 Pozri: Frič a kol., 2005: Veřejnost a elity jako aktéri modernizace. Praha: CESES FSV UK. Kriticky som to zhodnotil vo svojom príspevku (Stena 2016: 135-153).
} 
príležitostne ako sociálny útvar vyrastajúci z prostredia, ktoré nadobudlo kvalitu <pro-verejne> v „procese stávania sa“ (Sztompka 2007: 536-537). Subjektovost' verejnosti je tu poňatá procesuálne a interaktívne, a teda neznamená statické „byt' subjektom“ (Hausner 2014: 192). Niet dôvod subjektovost' verejnosti spájat's ,élan vital“, tobôž nie s autokinézou l'udí. Ako sa táto subjektovost' verejnosti transformuje na sociálneho aktéra?

$\mathrm{Na}$ vysvetlenie predkladám formou hypotézy ${ }^{26}$ model takého mechanizmu, pokúsim sa o to na dvoch úrovniach - najprv ho načrtnem na úrovni jednotlivca, pričom sa opriem o morfoüenetický prístup, následne na úrovni kolektivity s podporou myšlienok filozofie politiky.

$\mathrm{Na}$ úrovni indivídua to znamená odpovedat' na otázku, prečo príslušníci spoločenstva na problémové situácie každodenného života nereagujú rovnako, hoci sa ich takisto týkajú. Pri hl'adaní odpovede východiskom môže byt' téza M. S. Archerovej o reflexivite ${ }^{27}$ ako centrálnej zložke l'udskej subjektovosti. Tá sprostredkúva vzájomné pôsobenie medzi jednotlivcom, kultúrou a sociálnou štruktúrou. Ide pritom o stret dvoch kolekcií síl: objektívnych (vlastných kultúrnemu a sociálnemu kontextu) a subjektových, ktoré považujem za osobné dispozície jednotlivca. Stret týchto síl sa odohráva vo vnútri každého dospelého jedinca $\mathrm{v}$ rámci tzv. vnútornej konverzácie (inner conversation), ktorá je - ako to teoreticky ba i empiricky preukázala Archerová - prirodzenou výbavou každého človeka podobne ako reflexivita. V tejto intímnej hre spoluúčinkujú tak racionálne myšlienky, ako aj pocity, túžby, či spomienky na vlastné skúsenosti. Úlohou vnútorného dialógu jednotlivca je myšlienkovo spracovat' výzvy problémovej situácie v kontexte jeho životných starostî ${ }^{28}$ (concerns) vrátane starosti o celok spoločenstva a ustanovit' hierarchiu ich závažnosti. Pri hl'adaní riešenia ako d’alej postupovat' $\mathrm{v}$ problémovej situácii spoločenstva jednotlivec konfrontuje svoje osobné dispozície (ako l'udská bytost' je zakorenený v troch poriadkoch reality - prírodnom, praktickom a sociálnom) s danost’ami pomerov až kým nájde pre seba vhodné „,modus vivendi“. Akú dôležitost' pripíše účasti na riešení kolíznych pomerov, záleží tak od sociálno-kultúrneho systému $^{29}$, ako i od toho, aké významy on sám pripisuje vzt'ahom a udalostiam pod vplyvom absolvovanej socializácie. Pri tejto konfrontácii sa v l'ud'och

\footnotetext{
26 Doposial' sa v literatúre predmetu neobjavil pokus o sociologické vysvetlenie sociálneho mechanizmu pretvárania množiny osôb na verejnost’ v tvare sociálneho aktéra. A. Touraine i M. Castells opisujú mechanizmus zrodu sociálneho hnutia, problém verejnosti netematizujú.

27 „Reflexivita je regulárna realizácia mentálnej schopnosti, akou disponujú v̌̌etci normálni l'udia, vnímat' seba samých vo vzt'ahu k svojmu (sociálnemu) kontextu a vice versa." (Archer 2013: 21-22).

${ }^{28}$ Špecifická konštelácia „starostí“ nás definuje ako jedinečnú osobu s vlastnou osobnou identitou. Sme tým, čo nás trápi a zamestnáva, na čom nám záleží - tvrdí Archerová (2000: 10).

29 M. S. Archerová (2019) odlišuje systém kultúry (s harmonizovanými prvkami) od sociokultúrneho systému (vyjadruje kvalitu nepozbavenú protirečení odvíjajúcich sa od toho, ako l'udia uplatňujú prvky systému kultúry voči sebe navzájom).
} 
prebúdzajú emócie ${ }^{30}$ (chápané odlišne ako nálady) a tie vystupujú v úlohe hnacej sily praktického konania. Archerová ich definuje ako komentár $\mathrm{k}$ starostiam, ktoré nie sú iba stimulom (v podaní behaviorizmu), pretože obsahujú poznávací element (Archer 2000: 202). Prirodzene, vnútorný dialóg nie je imúnny voči omylom, ovplyvňujú ho súkromné médiá, ktoré sa podla P. Bourdieua (1998) môžu dopúšt'at' symbolického násilia v prospech záujmov ich vlastníka alebo hegemóna moci. Nie je vylúčené, že rozhodnutie jednotlivca dospeje kchybným záverom, svoju aktivitu nasmeruje na dráhu morfostázy ${ }^{31}$ namiesto morfogenézy, alebo sa vzdá účasti vo verejnom dianí.

Výsledné riešenie určujúce praktické konanie indivídua zúčastnit' sa verejného diania či nie vychádza z týchto osobnostných procesov a teda líši sa od človeka k človeku. Osoby nepripojené na siet' majú vol'bu jednoduchšiu: rozhodnú sa „vyvraviet"“ medzi svojimi (únik do súkromia). Alebo sa rozhodnú zvažovat' účast' spolu s inými napr. na nátlakovej akcii - vstup do domény verejného je prechodom z pozície primárneho agensa (nemá vplyv na rozhodovanie, zostáva iba jeho objektom) do pozície kolektívneho agensa. Ten už predstavuje istý okruh osôb v spoločenstve usilujúcich artikulovat' svoj záujem, ktorí hladajú prienik s blízkymi záujmami ostatných, pričom ich záujmy nemusia byt' totožné. Dôležité je, že si takto utvárajú - hoci dočasnú skupinovú identitu. Až potom dochádza k premene kolektívneho agensa na kolektívneho aktéra, naplňujúceho verejné dejisko kolektívnym konaním. Osoby pripojené na siet' majú o niečo zložitejšiu vol'bu. Ak nechcú zostat' primárnym agensom, ostávajú im d'alšie dve možnosti: bud' prijmú účast' na kolektívnej akcii v roli aktéra, alebo zvolia „únikové“ riešenie - odreagujú sa na sociálnej sieti webu, t. j. v oblasti tzv. osobnej kvázi verejnosti, o ktorej už bola reč vyššie. Myslím, že netreba preceňovat' úlohu diskusných fór na internete, ak nevyzrejú do praktickej akcie - a to je častý prípad. Ako ukázal M. Castells na príklade „twiterových revolúcií “ v Severnej Afrike (2013), sociálne siete na webe skôr dobre slúžia pri mobilizácii zainteresovaných. Popritom sa vyskytujú prípady účasti na kolektívnej akcii motivované solidaritou.

Teraz prikročím $\mathrm{k}$ načrtnutiu sociálneho mechanizmu utvárania verejnosti na úrovni kolektivity. Ked' menšina nespokojná s pomermi $\mathrm{v}$ spoločenstve opúšt'a pozíciu primárneho agensa a stáva sa najprv kolektívnym agensom (ako som to opísal), sformuje sa mentálne MY. Zároveň to znamená, že niekto $\mathrm{v}$ spoločenstve sa ocitá v pozícii ONI, spravidla ten, kto stojí v pozadí iritujúceho

\footnotetext{
30 Ich prítomnost' v počínaní verejnosti nemožno ani teoreticky vylúčit', aj terénne pozorovania a empirické výskumy ukázali skôr prevahu emotívnosti, vášní i hnevu sprevádzajúcich bezmocnost'. Vyskytujú sa i vo verejných debatách, kde je emotívnost' spravidla potláčaná.

31 Morfogenéza (pojem prevzatý M. Archerovou od W. Buckleya) označuje procesy v komplexnej výmene medzi systémom a prostredím, ktoré vyúst'ujú do zmeny formy, štruktúry a stavu systému. Naproti tomu 'morfostáza' predstavuje procesy, ktoré udržiavajú danú formu, štruktúru a stav systému (porovnaj Archer 1995).
} 
problému, alebo nesie zodpovednost' za to, aby sa riešil. A to znamená, že jeho reputácia je vystavená skúške. Takže do jestvujúcej štruktúry spoločenstva sa spontánne vkliní front svojrázneho zápasu, aký predtým neexistoval. Jeho povaha je obsahovo variabilná, poväčšine má agonický ${ }^{32}$ charakter (zriedka antagonistický - vtedy ide o konflikt neriešitel'ný kompromisom). Vzt’ah MY/ONI je prejavom nielen pribudnutia rozdielnosti medzi príslušníkmi spoločenstva, ale aj nevykorenitel'ným atribútom pospolitého života, ktorý sa označuje slovom politickost'. V prístupoch založených na konfliktualistickom poňatí sociálnej reality, aké zastával $\mathrm{M}$. Weber ${ }^{33}$ a po ňom rad vplyvných autorov (Bourdieu, Dahrendorf, Touraine), je politickost' chápaná v kontexte mocenskej hegemónie. Pritom nejde o politiku v profesiovom zmysle slova, ako to zdôrazňuje Ch. Mouffe (2005: 9). Politickost' je črtou situácie, ktorá $\mathrm{v}$ problémových konšteláciách sprevádza vol'bu z viacerých alternatív pri prijímaní riešenia (ked’že rozhodnutie sa vždy dotkne niekoho záujmu). L'udia takú vol'bu podstupujú bez toho, aby si politickost' uvedomovali. Pre náš prípad je dôležité, že na rozdiel od Carla Schmitta, ktorý zápas chápal v kategóriách priatel' verzus nepriatel', za Mouffeovou budeme uvažovat' o bipolarite v kategórii „protivníci“. To znamená, že tak MY ako aj ONI patria do spoločného symbolického priestoru a navzájom uznávajú svoju legitimitu.

MY ako kolektívny aktér je v takom zápase schopný aktívne vplývat' na dianie a vývoj spoločenstva. Jeho úlohou je spravidla hl’adat' riešenie kolíznej situácie, ked' deprivujúce podmienky hromadne l'ud'om neumožňujú uspokojovat' svoje potreby, ich ambície, alebo v prudkej dynamike spoločenských zmien cítia ohrozenie svojej ontologickej bezpečnosti (Giddens 1998: 85-91). Na rozdiel od inštitúcií štátu, ktoré $\mathrm{v}$ takom zápase neraz používajú tvrdú moc a korporátna moc uplácanie, alebo sa uchyl'uje k manipulácii faktov (cez médiá, právne služby), verejnost' ako kolektívny aktér zväčša narába s „mäkkou mocou“ (persuázia, hrozba, ironizovanie, únik neoprávnene utajovaných informácií alebo iné formy odporu). Na tomto mieste treba jednoznačne odlíšit' počínanie verejnosti $\mathrm{v}$ tvare aktéra od násilného davového konania, do akého niekedy zhromaždenia prerastajú, lebo tým dochádza $\mathrm{k}$ transformácii na už inú ontologickú kvalitu. V takom prípade už nejde o verejnost', ale dav, nič na tom nemení skutočnost', že sa násilnosti odohrávajú verejne (v zmysle atribútového pojmového určenia).

Je pravda, že rozšírené používanie internetu rozmnožilo príležitosti vytvárat' takéto dočasne trvajúce zoskupenia a teda potenciálne schopné vývinu do

\footnotetext{
32 Termín „agonický“ pochádza zo starogréckeho slova „agón“, ktoré má niekol’ko významov: sút’až, zápas, scéna prudkej hádky medzi hercami v gréckej dráme.

33 „Weber jednoznačne uprednostňuje dimenziu konfliktu ako primárnu danost' spoločenského života.“ Preto aj osobitné postavenie medzi sociálnymi vzt’ahmi pripisuje „boju (...), a to tak medzi jednotlivcami, ako aj sociálnymi skupinami“ (Novosád 1997: 16).
} 
podoby sociálneho aktéra. Zrejme najúčinnejšou formou v načrtnutom súperení má fakt telesnosti, ako o ňom píše Judith Butler. „Zhromaždenie znamená viac ako to, čo na ňom bude povedané“ (2016: 11), ked’že k rečiam pridáva osobitný význam aktom performatívnosti ${ }^{34}$. Autorka teda rozširuje teóriu performatívnosti $\mathrm{z}$ aktu reči na účast' tela $\mathrm{v}$ akcii. Fakt, že sa viacero l'udí zhromaždí napr. pri proteste na námestí, nesie význam „ustanovenia“ témy spoločensky dôležitou a utvára jedinečnú emočnú pôsobnost' medzi nimi navzájom a solidarizujúcimi partnermi na sieti. Či sa združujeme fyzicky na námestí alebo virtuálne na sieti, platí, že zmysel suverenity l’udu sa nevyčerpáva aktom volieb, lebo v nich nevykonávame plné prenesenie suverenity zo všetkých na vybraných predstavitel'ov - ,akúsi čast' suverenity l'udu nemožno preniest'.“ (Tamže: 142). Sú to práva l'udí vyjadrit' svoj názor, právo na kritiku, prípadne na odpor a touto cestou sa podiel'at' na utváraní podmienok vlastného života i celého spoločenstva. Pravda, žiadne protestné zhromaždenie nemá legitímne oprávnenie vydávat' sa za vôl'u l'udu (tamže: 145).

Uvedené mechanizmy mi umožňujú pripomenút' $\mathrm{v}$ zhode $\mathrm{s}$ viacerými autormi (Mateus 2015: 78; Pachucki - Breiger 2010; 2011; Emirbayer Sheller 1999: 154), že verejnost' ako kolektívny aktér má intersticiálnu povahu. To znamená, že sa vynára všade tam, kde vzniká problémová situácia, nerešpektujúc hranice firiem, komunít, inštitúcií ani štátov. Masívne používanie internetu a sociálnych sietí na webe umožňuje propagovat' internú kolíznu situáciu krížom cez všetky hranice a riešit' ju na úrovni spoločnej akcie ${ }^{35}$, angažovanost'ou osôb z rôznych sociálnych skupín. Neraz je to prechod od osobnej kvázi verejnosti k dejisku verejného charakteru, ako boli spomínané.

Načrtnuté sociálne mechanizmy by zrejme bolo možné vystihnút' precíznejšie. Avšak v porovnaní s podobným výkladom Castellsa, príčinnú následnost' vyjadrujú priliehavejšie, ked' ten opisuje mechanizmus zrodu sociálnych hnutí. Castells ho vykresl'uje bez toho, aby si čo len povšimol, že jednotlivci - od ktorých jeho výklad začína - spolutvoria verejnost' či už ako kolektívny agens alebo kolektívny aktér. Absencia práve tohto momentu je prítomná v uvažovaní väčšiny autorov vrátane sociológov: prehliadajú zásadný fakt, že verejnost' o ktorej sa uvažuje už v oboch modalitách spolu - má povahu sociabilitného fermentu založeného na spontánnosti. To znamená, že je prameňom sociálnych pohybov v spoločenstve vyvierajúcich zdola - t. j. z každodenného života osôb nepodiel'ajúcich sa na výkone moci. (Pripodobnit' ho možno k prírodným

\footnotetext{
34 Judith Butler pojem performatívnosti vniesla do sociologického diskurzu publikáciou Gender Trouble: Feminism and the Subversion of Identity, New York: Routledge, 1999. V našom prípade je dôležitý význam slova, ako naň poukázal J. L. Austin o performatívnych výpovediach. Podl'a neho existujú situácie, ked' vyslovením autorizovanej formuly vytvárame novú skutočnost': napr. výrok „Vyhlasujem vás za manželov“ alebo „Korunujem Ťa za král’a“. V našom prípade plní funkciu ustanovujúcej formuly fyzická prítomnost' l'udí na akcii.

35 ,The public, like the multitude, is something more than the sum of its parts. It is a permanent and interstitial form of a free society. A power in itself." (Mateus 2015: 78).
} 
procesom v tkanivách živých organizmov - rozmnožovaniu baktérí pri infekcii alebo kvaseniu za účasti enzýmov). Z interakcií a dramatickost'ou poznačeného záujmového či názorového súperenia $\mathrm{v}$ spoločenstve - aké predstavuje verejnost' - sa s podporou aktivistov vyvinú sociálne hnutia ako organizovaná forma sociability či iné organizované zložky občianskej spoločnosti. Preto komplexne chápanú verejnost' netreba vnímat' ako protiklad organizovaných zložiek občianskej spoločnosti, práve naopak: verejnost' je ich prameňom (pareniskom). Inštitucionalizované združenia občanov alebo sociálne hnutia predstavujú len iné štádiá sociálnej integrácie, do ktorých verejnost' môže postupne mutovat', pričom $\mathrm{v}$ nich stráca pôvodnú mieru spontaneity a svojbytnosti. Sociálne hnutia a organizované zložky občianskej spoločnosti sa potom samé uchádzajú o podporu verejnosti. Je tu ešte jeden významný rozdiel: tie sa koncentrujú na určitý typ záujmu (ekologické osvetové, svojpomoc), verejnost' na rozdiel od nich nie je zameraná na žiaden vopred stanovený typ záujmu. A v tom sa zračí príznak univerzálneho pôsobenia verejnosti a jej plnšie uplatnenie $\mathrm{v}$ digitalizovanom svete.

Bez aktivujúcej sa verejnosti by príslušníci spoločenstva boli odkázaní len na typ participácie projektovanej riadiacou menšinou, čo by vyprázdňovalo zmysel demokratického usporiadania verejného života v spoločenstve. Jej významným regulatívnym prínosom - na rozdiel od masy a davu - je, že o jej priazeň sa rôzni aktéri uchádzajú a od nej získavajú reputáciu a tým aj usmernenie, čo je žiadané a prípustné (axiologický aspekt). Pravdaže, pri trende narastajúcej individualizácie životných štýlov takéto poslanie verejnosti slabne. Nie je to tak, že by verejnost' plnila úlohu ,vel'kého iného“, ktorý všetko dozoruje, naopak - verejnost' je názorovo, hodnotovo a emočne pestrá entita, ale vždy v nej určitý prúd alebo jej dejisko prevláda. Podobne uvažoval A. Touraine, ked’ písal o „dominujúcom interpretačnom diskurze“ (2007: 16), hoci jemu išlo skôr o doktrinálnu záležitost' ako napríklad „There is no alternative“. Hromadné pripojenie ludí na internet túto problematiku komplikuje, lebo na ňom založená sociálna komunikácia sa dostala do víru fake news, pseudoprávd, hoaxov, dokonca sa píše o návrate davov do diskusií na sieti, kde sa prejavuje vulgárnost' a osočovanie (Torres - Mateus 2015). To však neznamená, že ju možno glorifikovat' čoby panaceum voči strnulosti a zlyhaniam inštitúcií. Namieste je konštatácia: „Nicméně působení veřejnosti nebýva vždy toliko produktivní... Vlivy veřejnosti jednotlivce povzbuzují i matou“ (Mokrejš 2005: 18) a v živote spoločenstva verejnost' môže pôsobit' rozporne.

\section{Záver}

Problematika verejnosti, ako ukazuje rozrastajúce sa množstvo odborných štúdií, je vel'mi rozsiahlou tematickou oblast'ou. Vybrat' z nej klúčcové motívy 
pre konceptualizáciu tak, aby sa vedecké poznanie posúvalo vpred a zachovala sa priezračnost' pre čitatel'a, predstavuje pre autora zložitú vol'bu. V prezentovanom podaní zrejme vzniklo vel’a otázok, ktoré si vyžadujú väčšiu pozornost' alebo samostatné spracovanie. Prijatý ciel' štúdie si vyžiadal odhliadnut' od analýzy foriem, v akých sa komplexne chápaná verejnost' prejavuje, a tiež od funkcií, aké v spoločenstve plní. $\mathrm{K}$ tomu pripravujem osobitnú štúdiu teoreticko-empirického charakteru. Prezentovaná štúdia preukázala, že aplikácia morfogenetického prístupu v konceptualizácii umožňuje hlboký prienik do podstaty fenoménu verejnost', možno heuristicky prínosnejší než doteraz publikované. Príkladom sú sociologické štúdie, ktoré verejnost' definujú ako sociálnu skúsenost' a híbavo prenikajú do roviny jej symbolického sprostredkovania (Mateus, Quéré, Terzi). Nepochybne taký prístup odhal'uje dôležitú stránku fenoménu verejnosti, ale aspekt l'udskej skúsenosti je prítomný aj $\mathrm{v}$ iných javoch spoločenstva, takže dostatočne nešpecifikuje svojbytnost' pojmu „verejnost“" oproti iným kategóriám sociológie. V textoch iných vedných odborov - ako som ich v úvode spomenul - sa neraz verejnost' berie ako „čierna skrinka“ a spravidla sa málo prihliada na jej sociálne zakorenenie. Myslím, že sociologické poznanie slepé škvrny uvažovania o verejnosti úspešne vypíňa.

Ján Stena po štúdiu sociológie na Jagiellonskej univerzite v Krakove profesiovú dráhu začinal vo výskumnom kolektive A. Hirnera so zameraním na výskum sociálnej kontroly. Pokračoval ako vysokoškolský pedagóg a neskôr pôsobil ako vedecký pracovník Sociologického ústavu SAV. Tu po roku 1990 viedol riešitelský tím zameraný na výskum revitalizácie občianskej spoločnosti. Je autorom knižnej publikácie o spoločenskej kontrole (1986), prispel kapitolou do viacerých monografii. Publikoval sériu vedeckých štúdii o kritike, tolerancii, protestoch, parlamentných vol'bách a rozvoji demokracie na Slovensku. Po osamostatneni Slovenskej republiky pät' rokov pôsobil vo funkcii radcu analytika $v$ Kancelárii prezidenta SR, nasledujúcich pät' rokov ako poradca predsedu v Národnej rade SR. Je členom redakčnej rady časopisu SÚ SAV Sociológia. V posledných rokoch sa výskumne venuje otázkam sociológie verejného života.

\section{LITERATÚRA}

ARCHER, M. S., 1995: Realist Social Theory: The Morphogenetic Approach. Cambridge: Cambridge University Press.

ARCHER, M. S., 2000: Being Human: The Problem of Agency. Cambridge: Cambridge University Press.

ARCHER, M., 2013: Jak porządek społeczny wpływa na ludzkie sprawstwo? Refleksyjność jako mechanizm pośredniczący między strukturą a sprawstwem'. In: 
Mrozowicki, A. - Nowaczyk, O. - Szlachcicowa, I. (eds.) Sprawstwo: teorie, metody, badania empiryczne w naukach społecznych. Krakow: Nomos, s. 19-35.

ARCHER, M. S., 2019: Kultura I sprawczość. Miejsce kultury w teorii społecznej. Warszawa: Narodowe Centrum Kultury.

ARENDTOVÁ, H., 2009: Vita activa neboli O činném životě. Praha: Oikoymenh.

BIERÓWKA, J., 2017: Kompetencje dorosłych Polaków związane z poszukiwaniem informacji przez internet. Znaczenie konstekstu społecznego. Państwo i społeczeństwo (XVII), nr. 3., p. 161-178.

BOURDIEU, P., 1998: Teorie jednání. Praha: Karolinum.

BENHABIB, S., 1996: Models of Public Space: Hannah Arendt, the Liberal Tradition, and Jürgen Habermas. In: Habermas and the Public Sphere. Calhoun, Craig (ed.), Cambridge. The MIT Press, Fourth printing, p. 73-98.

BUTLER, J., 2016: Zapiski o performativnej teorii zgromadzeń. Warszawa: Wydawnictwo Krytyki politicznej.

CALHOUN, C., 2013: The Problematic Public: Revisiting Dewey, Arendt, and Habermas. In: The Tanner Lectures on Human Values: University of Michigan https://tannerlectures.utah.edu/Calhoun\%20Tanner\%20Lecture.pdf

CASTELLS, M., 2013: Sieci Oburzenia i nadzei. Ruchy społeczne w erze internetu. Warszawa: Wydawnictwo Naukowe PWN.

ČERNÍK, V. - VICENÍK, J., 2011: Úvod do metodológie spoločenských vied. Bratislava: IRIS.

DEAN, J., 2004: Kybersalony a občanská společnost. Přehodnocení veřejné sféry v nadnárodní technokultuře. In: Hrubec, M. (ed.) Globální spravedlnost a demokracie. Praha: Filosofia. ss. 193-225.

DEUZE, M., 2015: Media life. Život v médiích. Praha: Karolinum.

DEWEY, J., 2001: Rekonštrukcia liberalizmu. Z politickej filozofie klasického pragmatizmu. Bratislava: Kaligram.

DOLATA, U. - SCHRAPE, J., 2015: Masses, Crowds, Communities, Movements: Collective Action in the Internet Age. Social Movement Studies, pp. 1-18.

DUSSEL, E., 2008. Twenty Theses on Politics. Durham: Duke University Press.

EMIRBAYER, M. - SHELlER, M., 1999: Publics in History. Theory and Society, Vol. 28, No. 1., pp. 145-197.

ENJOLRAS, B. - STEEN-JOHNSEN, K., 2017: The Digital Transformation of the Political Public Sphere: A Sociological Perspective. In: Institutional Change in the Public Sphere. Views on the Nordic Model. Fredrik Engelstad, Híkon Larsen, Jon Rogstad, Kari Steen-Johnsen (eds.) Warsaw/Berlin: De Gruyter Open Ltd.

ETTINGER, P., 2018: Intimisierung des Öffentlichen? In: Ettinger P., et al. (ed.): Intimisierung des Öffentlichen: Zur multiplen Privatisierung des Öffentlichen in der digitalen Ära. Berlin: Springer-Verlag.

FERRARESE, E., 2015: Habermas: Testing the political. Thesis Eleven. Vol 130, Issue 1, pp. 58-73.

FRASER, N., 2007: Rozvíjení radikální imaginace. In: Hrubec, M. (ed.) Globální přerozdělování, uznání a reprezentace. Praha: Filosofia.

FRIČ, P. - NEKOLA, M. - PRUDKÝ, L., 2005: Veřejnost a elity jako aktéři modernizace. Praha: CESES FSV UK. 
GIDDENS, A., 1998: Důsledky modernity. Praha: Sociologické nakladatelství.

GRIPSRUD. J. - MOE, H. - MOLANDER, A. - MURDOCK, G., 2010: General Introduction. In: The Idea of Public Sphere: A reader. Lanham, MD: Lexington.

GÜMPLOVÁ, P., 2007: Modernita a úpadek veřejné sféry: koncept veřejnosti a deliberativní politiky v díle Hannah Arendtové a Jürgena Habermase. In: J. Šubrt (ed.), Historická sociologie. Plzeň: Aleš Čeněk. ss. 282-304.

GÜMPLOVÁ, P., 2008: Hannah Arendtová: Vita activa. Sociologický časopis/Czech Sociological Review Vol. 44, nr. 5, ss. 1041-1044.

HABERMAS, J., 1992/1996: Further Reflections on the public Spere. In: Calhoun, C. (eds.) Habermas and the public sphere. Cambridge: The MIT Press, Fourth printing, pp. 421-461.

HABERMAS, J., 1994: Faktizität und Geltung. Beiträge zur Diskurstheorie des Rechts und des demokratischen Rechtsstaats. Frankfurt am Main: Suhrkamp.

HABERMAS, J., 2000: Strukturální přeměna veřejnosti, Zkoumání jedné kategorie občanské společnosti. Praha: Filosofia.

HAUSNER, J., 2014: Podmiotowość: moje stronnicze podsumowanie cyklu seminaryjnego. Zarządzanie Publiczne Nr 3(29), ss. 177-193.

KAHN, R. - KELLNER, D., 2009: Opoziční politika a internet: kriticko-rekonstruktivní př́stup. Sociální studia/Social Studies, č. 2., ss. 99-115. Brno: Masarykova univerzita.

KATZ, J. E., (ed.) 2006: Machines that Become Us: The Social Context of Personal Communication Technology. London snd new York: Transaction Publishers.

KLEINSTÜBER, H. J., 2001: Habermas and the Public Sphere: From a German to a European Perspective. The Public, Vol. 8, Nr. 1, ss. 95-108.

LEONHARD, G., 2018: Technológia vs. humanita. Bratislava: Slovenská inovačná a energetická agentúra.

LIVINGSTONE, S., 2005: On the Relation Between Audiences and Publics. In: Audiences and Publics: When cultural engagement matters for the public sphere. Changing Media, Changing Europe Volume 2 Bristol: Intellect.

LOHISSE, J., 2003: Komunikační systémy. Socioantropologický pohled. Praha: Karolinum.

MAHONY, N. - NEWMAN, J. - BARNETT, C., 2010: Introduction: Reithink the Public. In: Rethinking the public. Innovations in research, theory and politics. Bristol: Policy Press.

MALINA, J. a kol., 2009: Antropologický slovník. Brno: Akademické nakladatelství CERM.

MATEUS, S., 2011: The Public of Social Experience. Comunicaçăo e Sociedade, vol. 19, pp. 275-286. Prístup: https://www.researchgate.net/publication/271014176

MATEUS, S., 2014: Visibility Regimes in Mediatized Publicness. MATRIZes, 8(2), 259281.

MATEUS, S., 2015: Publics and Multitudes: The (Un)Expected Relation. In: From Multitude to Crowds: Collective Action and the Media. Berlin: Peter Lang GmbH, pp. 71-87.

MATEUS, S., 2017: Visibility as a Key concept in Communication and Media Studies. Estudos em Comunicação no 25, vol. 2, 109-124.

MEYROWITZ, J., 2006: Všede a nikde. Vliv elektronických médií na chování. Praha: Karolinum.

NOVOSÁD, F., 1997: Osud a vol'ba. Max Weber ako diagnostik modernej kultúry. Bratislava: Iris. 
MOKREJŠ, A., 2005: Veřejnost: skutečnost - iluze - fikce. Praha: Triton.

PACHUCKI, M. - BREIGER, R., 2010: Cultural Holes: Beyond Relationality in Social Networks and Culture. Annu. Rev. Sociol. No. 36, pp. 205-224.

PRODNIK, J., 2011: A Public Sphere without Public(s)? Publics and Counterpublics in Post-Fordist Capitalism. In: Public Sphere Reconsidered. Theories and Practices Covilhã: LabCom Books. pp. 273-288.

ROVELLI, C., 2018: Realita není, čím se zdá. Cesta ke kvantové gravitaci. Praha: Dokořán \& Argo.

QUÉRÉ, L. - TERZI, C., 2015: Pour une sociologie pragmatiste de l'expérience publique. SociologieS. https://journals.openedition.org/sociologies/4949?lang=en\#text

SLAVÍK, L. - POSPĚCH, P., 2019: Youtuberství jako konstrukce, destrukce a reparace soukromí. Sociologický časopis, vol. 55, no. 2, ss. 135-159.

SPLICHAL S., 2012: Transnationalization of the Public Sphere and the Fate of the Public. New York: Hampton Press.

SPLICHAL, S., 2017: The (Re)Production of Publicness and Privateness in the Liquid Modern Society. http://www.nmi.hr/files/pdf/vol23-br2/02_splichal.pdf

STENA, J., 2015: Morfogenetický prístup v sociológii - ambivalentné prijatie a jeho inovačný potenciál. Sociológia 47(4), ss. 414-437.

STENA, J., 2016: Verejnost' - tradičné prístupy a konceptualizácie. In: Sociológia a každodennost'. Pocta dielu Dilbar Alievy. Sociologický ústav SAV, ss. 109-133.

STENA, J., 2016: Verejnost' - otváranie nových možností skúmania. In: Sociológia a každodennost'. Pocta dielu Dilbar Alievy. Sociologický ústav SAV, ss. 135-153.

STRANI, K., 2014: The Impact of Socio-Political Change on Public Sphere Theory Exploring the Relevance of Communicative Rationality. The International Journal of Cross-Cultural Studies and Environmental Communication. Volume 1, Issue 1, pp. 3140.

STRUM, A., 1994: A Bibliography of the Concept Offentlichkeit. New German Critique, No. 61, Special Issue on Niklas Luhmann, pp. 161-202.

SZTOMPKA, P., 2007: Socjologia. Analiza społeczeństwa.Kraków: Znak.

ŠMÍDOVÁ-MATOUŠOVÁ, O., 2012: „Rudé právo psalo, že nás bylo málo...“ Restituce identity a identita restituce v diskurzu Rudého práva v roce nula. Praha: Slon.

THOMPSON, J. B., 2004: Médiá a modernita. Sociální teorie médií. Praha: Karolinum.

TONKLI-KOMEL, A., 2012: Politickost' v iných javových podobách Hannah Arendt. Filozofia, roč. 27, č. 10, ss. 805-818.

TUBELLA, I., 2004: Television and Internet in the Construction of Identity. In: Castells, M. - Cardoso, G. (eds.): The Network Society From Knowledge to Policy. Washington: Center for Transatlantic Relations.

TORRES, E. C. - MATEUS, S., 2015: Introduction. In: From Multitude to Crowds: Collective Action and the Media. Berlin: Peter Lang GmbH. pp. 11-22.

TOURAINE, A., 2007: Myśleć inaczej. Warszawa: Państwowy Instytut Wydawniczy.

URBINATI, N., 2018: Znetvořená demokracie: mínění, pravda a lid. Praha: Karolinum.

WARNER, M., 2002: Publics and Counterpublics. New York: Zone Books. 